\title{
A chemoenzymatic synthesis of ceramide trafficking inhibitor HPA-12
}

\author{
Seema V. Kanojia ${ }^{1}$, Sucheta Chatterjee ${ }^{1}$, Subrata Chattopadhyay ${ }^{1}$ \\ and Dibakar Goswami ${ }^{*} 1,2$
}

\author{
Full Research Paper \\ Address: \\ ${ }^{1}$ Bio-Organic Division, Bhabha Atomic Research Centre, Mumbai \\ 400 085, India and ${ }^{2}$ Homi Bhabha National Institute, Training School \\ Complex, Anushakti Nagar, Mumbai 400 094, India \\ Email: \\ Dibakar Goswami - dibakarg@barc.gov.in \\ * Corresponding author \\ Keywords: \\ AD mix- $\beta$; [bmim] $\left[P F_{6}\right]$; DDQ; HPA-12; lipase
}

Beilstein J. Org. Chem. 2019, 15, 490-496. doi:10.3762/bjoc. 15.42

Received: 03 October 2018

Accepted: 26 January 2019

Published: 18 February 2019

Associate Editor: S. Bräse

(c) 2019 Kanojia et al.; licensee Beilstein-Institut. License and terms: see end of document.

\begin{abstract}
A chemoenzymatic synthesis of the title compound has been developed using an efficient and highly enantioselective lipase-catalyzed acylation in a hydrophobic ionic liquid, $\left[\mathrm{bmim}_{[}\left[\mathrm{PF}_{6}\right]\right.$, followed by a diastereoselective asymmetric dihydroxylation as the key steps for incorporating the stereogenic centers. The further conversion to the appropriate intermediates and subsequent acylation with lauric acid furnished the target compound.
\end{abstract}

\section{Introduction}

Ceramides belong to the family of sphingolipids (SLs) and are synthesized de-novo in the endoplasmic reticulum (ER) [1] Once formed, ceramide transport protein (CERT), a $68 \mathrm{kDa}$ cytosolic protein, delivers the compound to the Golgi apparatus for further conversion to sphingomyelins, which play important roles in cell-signaling pathways [2]. In the last few years, the downregulation of CERT-mediated ceramide transfer from the ER to Golgi has gained increased attention in antioncogenic as well as antineurodegenerative therapeutic research [3-10]. However, chemical entities which inhibit CERT are scarce. In 2001, Hanada et al. reported $(1 R, 3 R)-N$-(3-hydroxy-1-hydroxymethyl3-phenylpropyl)dodecanamide (HPA-12, 1, Figure 1) as the first inhibitor of CERT-mediated ceramide transport [11]. How- ever, the initially determined $(1 R, 3 R)$ configuration of the most active HPA-12 stereoisomer (compound 1, Figure 1) was later revised to $(1 R, 3 S)$ configuration (compound $\mathbf{2}$, Figure 1 ) by Berkeš et al. in 2011 [12]. Since then, HPA-12 has been the subject of extensive biological evaluation. The HPA-12-mediated CERT knockdown has been associated with restoration of cell death in paclitaxel-resistant ovarian cancer cells [3] and also with the increased rate of ceramide-induced apoptosis following UVB irradiation, suggesting the possibility of its use as an anticancer compound. Besides, inhibition of sphingolipid biosynthesis using HPA-12 has also been reported to inhibit hepatitis $\mathrm{C}$ virus replication substantially [4]. In another study, the CERT knockdown disrupted the normal oxidative stress 
response in Drosophila [5]. More recently, a fluorinated analogue of HPA-12 has been studied for its BBB permeability and subsequent brain uptake, showcasing its possible use in neurodegenerative disorders [9].<smiles>CCCCCCCCCCCC(=O)N[C@@H](CO)C[C@@H](O)c1ccccc1</smiles>

$(1 R, 3 R)-\mathrm{HPA}-12(1)$<smiles>CCCCCCCCCCCC(=O)N[C@H](CO)C[C@@H](O)c1ccccc1</smiles>

(1R, 3S)-HPA-12 (2)
Figure 1: Structure of most active HPA-12 isomers, originally proposed (1) and revised (2).

However, a limited commercial availability and high cost of HPA-12 have hindered its application in basic researches involving CERT inhibition. For this, a number of groups have successfully accomplished the synthesis of HPA-12 [13-25]. The first synthesis of HPA-12 comprised [13] a three-component asymmetric Mannich reaction catalyzed by a chiral zirconium catalyst. However, after the structural revision of the most active stereoisomer, Kobayashi et al. synthesized ( $1 R, 3 S)$-HPA12 (2, Figure 1) using a Zn-catalyzed asymmetric Mannich-type reaction in water, and unambiguously ascertained the revised configuration by X-ray crystallography [14]. The other syntheses of $(1 R, 3 S)$-HPA-12 (2) used the chiral pool approach $[15,16]$, crystallization-induced asymmetric transformation [17], diastereoselective reduction of $\gamma$-aryl- $\gamma$-oxo- $\beta$-amino alcohol [18], cycloaddition of oxime with alkenes [19], enantioselective carbonyl reduction followed by an organocatalyzed $\alpha$-amination reaction [20], tandem approach from $(S)$-Wynberg lactone [21], chiral ruthenium-catalyzed $N$-demethylative rearrangement of 1,2-isoxazolidines [22], gold(I)-catalyzed cycliza- tion of a propargylic $N$-hydroxylamine [23], from $\beta$-sulfinamido ketones derived from chiral sulfinimines [24], and a Kornblum-DeLaMare/aza-Michael reaction of 3,6-dihydro-1,2dioxines followed by diastereoselective reduction [25]. Most of these methods employ starting materials or catalysts, which are not commercially available, and also require operationally demanding reaction conditions. Hence a need to develop a simple, efficient and inexpensive synthesis of HPA-12 was felt. Our own interest in developing anticancer agents also prompted us to develop a new and practical enantioselective synthesis of 2 [26-29].

To realize our objective, we paid particular attention to obtain 2 using reactions that are high-yielding and can be executed under simple reaction conditions with commercially available and inexpensive materials/reagents. In this regard biocatalytic reactions offer green and sustainable alternative routes to develop asymmetric syntheses of pharmaceuticals with varied stereochemical features [30-33]. Our group has been using lipases for the chemoenzymatic syntheses of several bioactive molecules [34-39]. The prevalence of $\mathrm{PhCH}(\mathrm{OH})$ in 2, and in many other biochemicals, attracted our attention to formulate an enantioselective lipase-catalyzed transacetylation strategy to obtain a suitable molecule bearing the designated chiral segment (compound 2, vide infra).

\section{Results and Discussion}

For the synthesis, commercially available benzaldehyde (3) was allylated using $\mathrm{Zn} /$ allyl bromide in moist THF following Luche's protocol to obtain the homoallylic alcohol $( \pm)-4$ (Scheme 1) [40]. We envisaged that the enantiomers of 4 were ideal substrates for the asymmetric synthesis of different stereoisomers of 2. Several biocatalytic protocols for the preparation of $(R)$ or $(S)-\mathbf{4}$ were reported earlier. The hydrolysis of the corresponding acetate with crude enzyme preparations from pig<smiles>CC(C)=CCC(O)c1ccccc1</smiles><smiles>[R]O[C@H](CC=C)c1ccccc1</smiles>

(S)-4a 
liver and chicken liver esterase proceeded with modest enantioselectivity [41,42]. Rhizopus arrhizus-mediated hydrolysis of the acetate furnished the enantiomerically pure alcohol $(99 \%$ ee), however, the enantiomeric excess (ee) of the antipode acetate was very poor (5-9\%) [43]. On the other hand, the Amano PS lipase-catalyzed trans-acylation of $( \pm)$-4 furnished $(S)$-4 with good ees, while the ee of the $(R)$-acetate was poor [44]. The acylase 1-catalyzed resolution protocol gave $(S)-4$ in a poor $\%$ ee [45]. A unified approach where both the enantiomers of $\mathbf{4}$ are obtained in good optical purities is rare. This is important as the individual enantiomers can be converted to the antipodes by Mitsonobu inversion [46], thereby maximizing the yield of the desired enantiomer. In addition, the availability of both the enantiomers of $\mathbf{4}$ would be useful for the synthesis of all diastereomers of $\mathbf{2}$ (as per our synthetic plan) and also several other pharmacologically important compounds. To the best of our knowledge, only the lipase PS-catalyzed acylation of $( \pm)-4$ proceeded with good to excellent ees for both the acetate and alcohol. However, details of the protocol are unavailable, and also the resolution was quite slow [47]. Hence, we screened different lipases for the trans-acetylation of $( \pm)-\mathbf{4}$ for its effective resolution and the results are summarized in Table 1. Based on our past experience in lipase-catalyzed resolution of homoallylic alcohols [38], initially a Novozym $435^{\circledR}$-catalyzed acetylation of $( \pm)-4$ with vinyl acetate in diisopropyl ether (DIP) was attempted. However, the yield and enantioselectivity of the desired alcohol $(S)-4$ were very poor (Table 1 , entry 1$)$. Also the acetylation of $( \pm)-\mathbf{4}$ with vinyl acetate in diisopropyl ether using Candida rugosa lipase (CRL) and Pseudomonas fluorescens lipase (PFL) were futile (Table 1, entries 2 and 3). In contrast, a better yield and enantiocontrol was achieved using Amano lipase from $P$. fluorescens (Amano PFL) in conjunction with vinyl acetate in diisopropyl ether, where the $(R)$-acetate $\mathbf{5}$ and $(S)$-alcohol 4 were obtained in $85 \%$ and $88 \%$ ee, respectively, at $48 \%$ conversion after $192 \mathrm{~h}$ (Table 1, entry 4). The efficacy of Amano PFL for the resolution of $( \pm)-\mathbf{4}$ is in corroboration with the reported method using Amano lipase PS [44]. However, since the reaction was very slow, we attempted to improve the reaction rate by carrying out the resolution at $50{ }^{\circ} \mathrm{C}$, near the optimum temperature of the enzyme $\left(55^{\circ} \mathrm{C}\right)$. Under these conditions, a 50\% conversion was achieved within $48 \mathrm{~h}$ to obtain both (R)-5 and (S)-4 in $90 \%$ ee (Table 1, entry 5). A second acetylation (12\% conversion, $20 \mathrm{~h})$ of the resolved $(S)-4$ under the same conditions improved its ee to $99 \%$ (Table 1 , entry 6). The products were isolated by filtering the insoluble enzyme from the reaction mixture, followed by concentration of the filtrate. The obtained residue was subjected to silica gel column chromatography to isolate unreacted alcohol and acetylated product. We have reused the recovered lipase at least three times without any significant loss of enzyme activity.

There are similar instances in literature [48] for a substantial slow-down of the transesterification reaction rate in organic solvents. This issue can be overcome by using room temperature

\begin{tabular}{|c|c|c|c|c|c|c|c|c|c|c|c|}
\hline Entry & Lipase & $\begin{array}{l}\text { Acylating } \\
\text { agent }\end{array}$ & Solvent & $\begin{array}{l}\text { Time } \\
\text { (h) }\end{array}$ & $\begin{array}{l}\% \\
\text { Conversion }\end{array}$ & $\begin{array}{l}\% \text { ee of } \\
(S)-4^{a}\end{array}$ & $\begin{array}{l}\% \text { ee of } \\
(R)-5^{a}\end{array}$ & $\% c^{b}$ & $\begin{array}{l}\text { Yield of } \\
\text { enriched } \\
(S)-4^{c}\end{array}$ & $\begin{array}{l}\text { Yield of } \\
\text { enriched } \\
(R)-5^{C}\end{array}$ & $E^{d}$ \\
\hline 1 & Novozym 435 & $\begin{array}{l}\text { vinyl } \\
\text { acetate }\end{array}$ & DIP & 96 & 20 & 22 & 71 & 23.7 & 76 & 16 & 7.21 \\
\hline 2 & CRL & $\begin{array}{l}\text { vinyl } \\
\text { acetate }\end{array}$ & DIP & 72 & 23 & 19 & 68 & 21.8 & 71 & 20 & 6.35 \\
\hline 3 & $\begin{array}{l}\text { Lipase from } \\
P \text {. fluorescens }\end{array}$ & $\begin{array}{l}\text { vinyl } \\
\text { acetate }\end{array}$ & DIP & 96 & 26 & 35 & 89 & 28.2 & 67 & 21 & 24.58 \\
\hline 4 & Amano PFL & $\begin{array}{l}\text { vinyl } \\
\text { acetate }\end{array}$ & DIP & $192^{\mathrm{e}}$ & 48 & 88 & 85 & 50.9 & 45 & 42 & 35.40 \\
\hline 5 & Amano PFL & $\begin{array}{l}\text { vinyl } \\
\text { acetate }\end{array}$ & DIP & $48^{f}$ & 50 & 90 & 90 & 50.0 & 46 & 43 & 58.75 \\
\hline 6 & Amano PFL & $\begin{array}{l}\text { vinyl } \\
\text { acetate }\end{array}$ & DIP & 20 & $12^{\mathrm{g}}$ & 99 & ND & ND & 82 & 10 & ND \\
\hline 7 & Amano PFL & $\begin{array}{l}\text { vinyl } \\
\text { acetate }\end{array}$ & $\begin{array}{l}{[\mathrm{bmim}]} \\
{\left[\mathrm{BF}_{4}\right]}\end{array}$ & 48 & $10^{e}$ & ND & ND & ND & ND & ND & ND \\
\hline 8 & Amano PFL & $\begin{array}{l}\text { vinyl } \\
\text { acetate }\end{array}$ & $\begin{array}{l}{[\mathrm{bmim}]} \\
{\left[\mathrm{PF}_{6}\right]}\end{array}$ & $6^{f}$ & 48 & 92 & 91 & 50.3 & 45 & 42 & 68.62 \\
\hline
\end{tabular}

aExperimentally determined from chiral HPLC analysis using AD- $\mathrm{H}$ column and $5 \%$ isopropanol/hexane as eluent @1.0 $\mathrm{mL} \mathrm{min}{ }^{-1}, \lambda=254 \mathrm{~nm}$. ${ }^{\mathrm{b}}$ The $\% c$ values were calculated from the enantiomeric excess of the starting material $\left(e e_{s}\right)$ and the product $\left(e e_{p}\right)$ according to $\% c=e e_{s} /\left(e e_{s}+e e_{p}\right)$. ${ }^{c}$ Isolated yield. ${ }^{\mathrm{d}}$ The enantiomeric factor $(E)$ was calculated from the enantiomeric excess of the starting material (ee ${ }_{\mathrm{s}}$ ) and the $\mathrm{c}$ value according to $E=\ln \left[(1-c)\left(1-e_{s}\right)\right] / \ln \left[(1-c)\left(1+e_{s}\right)\right.$. e Reaction done at $25^{\circ} \mathrm{C}$. ${ }^{f}$ Reaction done at $50^{\circ} \mathrm{C}$. gReaction done on the partially resolved alcohol obtained from the previous entry. 
ionic liquids, which not only substitute the environment damaging organic solvent, but also increase the reaction rate, and provide many other technological advantages [49]. Towards this, we have chosen $[\mathrm{bmim}]\left[\mathrm{BF}_{4}\right]$ and $\left[\mathrm{bmim}^{2}\left[\mathrm{PF}_{6}\right]\right.$ as two model ionic liquids. Of them, $[\mathrm{bmim}]\left[\mathrm{BF}_{4}\right]$ is water soluble, and $[\mathrm{bmim}]\left[\mathrm{PF}_{6}\right]$ is immiscible with water. The acetylation of $( \pm)-\mathbf{4}$ with vinyl acetate in $[\mathrm{bmim}]\left[\mathrm{BF}_{4}\right]$ using Amano PFL was very slow (Table 1, entry 7), showing only $10 \%$ completion after $48 \mathrm{~h}$. Carrying out the reaction at $50{ }^{\circ} \mathrm{C}$ also did not improve the reaction rate. However, the acetylation in $[\mathrm{bmim}]\left[\mathrm{PF}_{6}\right]$ at $50{ }^{\circ} \mathrm{C}$ using vinyl acetate and Amano PFL was much faster (Table 1 , entry 8 ), and a $48 \%$ conversion was achieved in only $6 \mathrm{~h}$ to obtain $(R)-5$ and (S)-4 in $91 \%$ and $92 \%$ ee, respectively. This kind of dependency of the reaction rate on the nature of the anion in the ionic liquid has been reported earlier [50]. Whatsoever, the reaction protocol in $[\mathrm{bmim}]\left[\mathrm{PF}_{6}\right]$ was fruitful for the successful resolution of racemic $( \pm)-4$. The products were extracted from the $[\mathrm{bmim}]\left[\mathrm{PF}_{6}\right]$ medium with diethyl ether and the ethereal phase was concentrated. The residue was then subjected to silica gel column chromatography to obtain the unreacted alcohol and the acetate. We have reused the recovered lipase in ionic liquid at least three times without any significant loss of enzyme activity.

The \% ee of the $(R)-5$ and $(S)-\mathbf{4}$ were determined from chiral HPLC analyses $(150 \mathrm{~mm} \times 4.6 \mathrm{~mm}, 5 \mu \mathrm{m}$, chiral AD-H

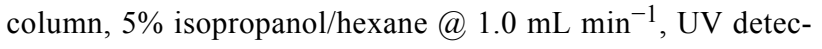
tion at $254 \mathrm{~nm}$ ). The absolute configurations of $(R)-\mathbf{5}$ and $(S)-\mathbf{4}$ were assigned by comparison of the chiroptical data with those reported [45]. The stereochemical outcome of the reaction is consistent with Kazlauskas' empirical rule [51]. The conversion (\% c) and the enantiomeric excess (E) values were calculated according to the method described by Sih et al. [52]. Besides the high yield and \% ee, the biocatalytic protocol is operationally simple and convenient. We carried out the transformation using inexpensive vinyl acetate as the acyl donor due to its volatility that would assist easy isolation of the products.
All the reactions were carried out at least 3-4 times and the best results are presented in Table 1. To the best of our knowledge, this is the first attempt towards the resolution of $( \pm)-4$ in a room temperature ionic liquid at an elevated temperature.

To make the synthesis enantio-convergent, and also to offset the limitations of a resolution-based protocol, $(R)-5$ was hydrolyzed with alcoholic $\mathrm{KOH}$ to furnish $(R)-4$ (Scheme 1). Its inversion under the Mitsunobu conditions $\left(\mathrm{Ph}_{3} \mathrm{P} / \mathrm{DIAD} / p\right.$ nitrobenzoic acid/THF; $\mathrm{KOH} / \mathrm{EtOH} / 25^{\circ} \mathrm{C} / 8 \mathrm{~h}, 91 \%$ over two steps) gave (S)-4 [46]. The benzylation of the hydroxy function in $(S)-4$ with benzyl bromide $(\mathrm{BnBr})$ and $\mathrm{Bu}_{4} \mathrm{NI}$ in the presence of $\mathrm{NaH}$ produced compound $\mathbf{6}$ (Scheme 2). This was subjected to asymmetric dihydroxylation (ADH) using $\mathrm{AD}$ mix $-\beta$ $\left.\left[\mathrm{K}_{2} \mathrm{OsO}_{2}(\mathrm{OH})_{4} \text { and (DHQD) }\right)_{2}-\mathrm{PHAL}\right]$. The reaction proceeded predominantly from the $\alpha$-face, resulting in the formation of the 1,3-anti diol 7a and 1,3-syn diol $\mathbf{7 b}$ in a 91:9 ratio (based on the isolated yields of $\mathbf{7 a}$ and $\mathbf{7 b}$, separated by column chromatography). Previously the ADH reaction of a homologue of $\mathbf{6}$, bearing a methyl substitution and a hydroxy group (instead of benzyloxy group) with AD mix- $\beta$ also produced the corresponding $\alpha$-alcohol [53]. However, unlike in our case, the reaction proceeded with poor diastereoselectivity irrespective of the dihydroxylating agent used. To confirm the 1,3-anti diol stereochemistry of $7 \mathbf{a}$, it was debenzylated using DDQ/ $/ \mathrm{CH}_{2} \mathrm{Cl}_{2}-\mathrm{H}_{2} \mathrm{O}$ to furnish the trihydroxy compound $7 \mathbf{a}^{\prime}$. The ${ }^{1} \mathrm{H}$ and ${ }^{13} \mathrm{C}$ NMR spectra, and the optical rotation of $\mathbf{7} \mathbf{a}^{\prime}$ were in conformity with those reported [54]. In addition, the 1,3-anti stereochemistry of the diol 7a was confirmed by converting it to the target compound $\mathbf{2}$, and comparing its chiroptical data with the reported values, as described afterwards.

For the synthesis of $\mathbf{2}$, the primary hydroxy function of $\mathbf{7 a}$ was benzoylated to get $\mathbf{8}$. Compound $\mathbf{8}$ was mesylated with methanesulfonyl chloride $(\mathrm{MsCl}) / \mathrm{Et}_{3} \mathrm{~N}$ and the product reacted with $\mathrm{NaN}_{3} / \mathrm{DMF}$ at $90{ }^{\circ} \mathrm{C}$ to obtain the azide 9 (Scheme 2). We first attempted to convert 9 to the target compound $\mathbf{2}$ by i)

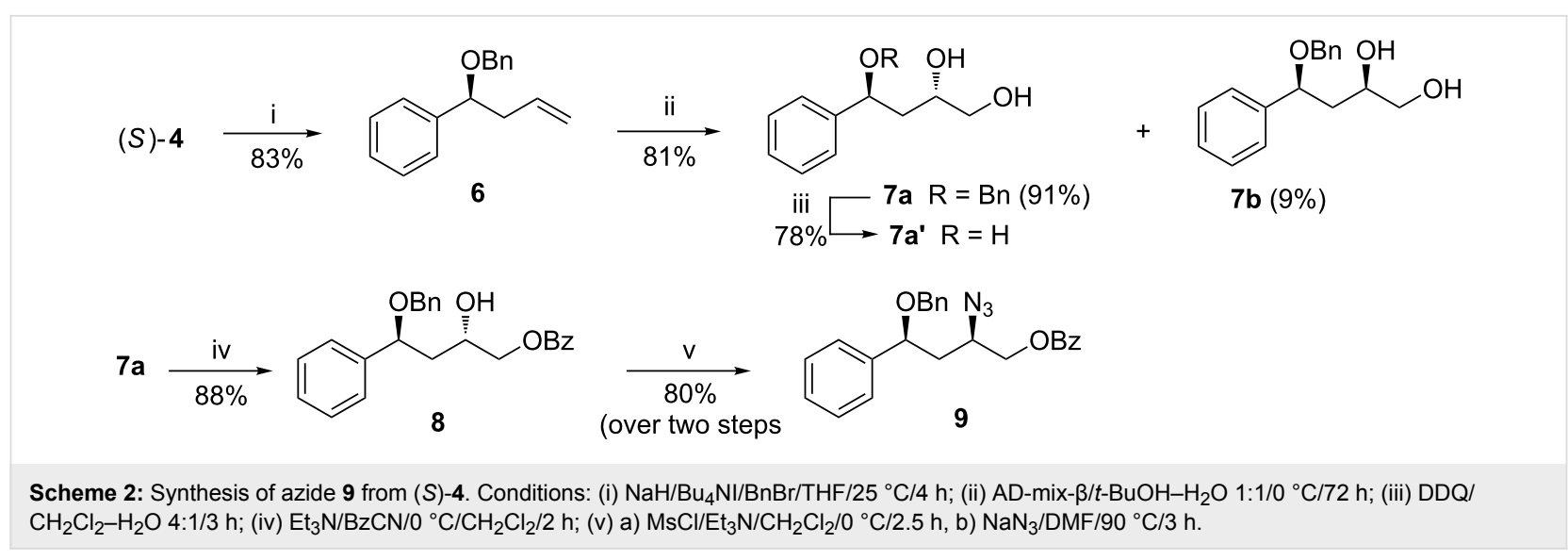


converting the azide group to the amine using $\mathrm{LiAlH}_{4}$ with concomitant debenzoylation, followed by the acylation of the amine with lauric acid to afford $9 \mathbf{a}$, and finally, ii) reductive cleavage by hydrogenolysis using $\mathrm{Pd}-\mathrm{C} / \mathrm{H}_{2}$ leading to debenzylation (Scheme 3). However, during hydrogenolysis, the elimination of the -OBn group led to product $9 \mathbf{b}$, which was undesirable. A similar elimination was earlier observed by Sharf et al. during hydrogenolysis of dibenzyl ether [55]. To avoid this, an oxidative debenzylation of 9a using DDQ/ $\mathrm{CH}_{2} \mathrm{Cl}_{2}-\mathrm{H}_{2} \mathrm{O}$ was carried out. However, this led to a very poor yield of the target compound 2 (Scheme 3). Hence, we decided to debenzylate compound 9 prior to its reduction to the amine and subsequent acylation. Towards this (Scheme 4), oxidative debenzylation of $\mathbf{9}$ using DDQ yielded $\mathbf{1 0}$ in $84 \%$ yield. Treatment of $\mathbf{1 0}$ with $\mathrm{LiAlH}_{4}$ led to the reduction of the azide group to amine along with debenzoylation to furnish an intermediate aminodiol, which, without further purification, was acylated with lauric acid in the presence of dicyclohexylcarbodiimde (DCC) and 4-dimethylaminopyridine (DMAP) to give the target compound HPA-12 $(1 R, 3 S)$-2. The optical and spectroscopic data of compound 2 were in accordance with those reported [18].

\section{Conclusion}

In summary, we have demonstrated an efficient protocol for the synthesis of HPA-12 using a lipase-catalyzed resolution of the alcohol $( \pm)-\mathbf{4}$ in an ionic liquid and a diastereoselective ADH reaction as the key steps. The synthesis was accomplished by employing reactions that use inexpensive reagents, are operationally simple and proceed with good to excellent yields and excellent stereoselectivities. The target compound was obtained in $23 \%$ overall yield starting from $(S)-4$. The protocol can also be used to access different HPA analogues and derivatives.

\section{Supporting Information}

\section{Supporting Information File 1}

Experimental details and analytical data.

[https://www.beilstein-journals.org/bjoc/content/ supplementary/1860-5397-15-42-S1.pdf]

\section{Supporting Information File 2}

NMR spectra.

[https://www.beilstein-journals.org/bjoc/content/ supplementary/1860-5397-15-42-S2.pdf]

\section{References}

1. Hannun, Y. A.; Obeid, L. M. Nat. Rev. Mol. Cell Biol. 2008, 9, 139-150. doi:10.1038/nrm2329

2. Hanada, K.; Kumagai, K.; Yasuda, S.; Miura, Y.; Kawano, M.; Fukasawa, M.; Nishijima, M. Nature 2003, 426, 803-809. doi:10.1038/nature02188 
3. Swanton, C.; Marani, M.; Pardo, O.; Warne, P. H.; Kelly, G.; Sahai, E.; Elustondo, F.; Chang, J.; Temple, J.; Ahmed, A. A.; Brenton, J. D.; Downward, J.; Nicke, B. Cancer Cell 2007, 11, 498-512. doi:10.1016/j.ccr.2007.04.011

4. Sakamoto, H.; Okamoto, K.; Aoki, M.; Kato, H.; Katsume, A.; Ohta, A.; Tsukuda, T.; Shimma, N.; Aoki, Y.; Arisawa, M.; Kohara, M.; Sudoh, M. Nat. Chem. Biol. 2005, 1, 333-337. doi:10.1038/nchembio742

5. Rao, R. P.; Yuan, C.; Allegood, J. C.; Rawat, S. S.; Edwards, M. B.; Wang, X.; Merrill, A. H., Jr.; Acharya, U.; Acharya, J. K. Proc. Natl. Acad. Sci. U. S. A. 2007, 104, 11364-11369. doi:10.1073/pnas.0705049104

6. Kujjo, L. L.; Acton, B. M.; Perkins, G. A.; Ellisman, M. H.; D’Estaing, S. G.; Casper, R. F.; Jurisicova, A.; Perez, G. I. Mech. Ageing Dev. 2013, 134, 43-52. doi:10.1016/j.mad.2012.12.001

7. Kumagai, K.; Kawano-Kawada, M.; Hanada, K. J. Biol. Chem. 2014, 289, 10748-10760. doi:10.1074/jbc.m113.528380

8. Fleury, L.; Faux, C.; Santos, C.; Ballereau, S.; Génisson, Y.; Ausseil, F. J. Biomol. Screening 2015, 20, 779-787. doi: $10.1177 / 1087057115573402$

9. Crivelli, S. M.; Paulus, A.; Markus, J.; Bauwens, M.; Berkes, D.; De Vries, H. E.; Mulder, M. T.; Walter, J.; Mottaghy, F. M.; Losen, M.; Martinez-Martinez, P. J. Alzheimer's Dis. 2017, 60, 783-794. doi:10.3233/jad-161231

10. Scheiblich, H.; Schlütter, A.; Golenbock, D. T.; Latz, E.; Martinez-Martinez, P.; Heneka, M. T. J. Neurochem. 2017, 143, 534-550. doi:10.1111/jnc.14225

11. Yasuda, S.; Kitagawa, H.; Ueno, M.; Ishitani, H.; Fukasawa, M.; Nishijima, M.; Kobayashi, S.; Hanada, K. J. Biol. Chem. 2001, 276, 43994-44002. doi:10.1074/jbc.m104884200

12. Ďuriš, A.; Wiesenganger, T.; Moravčíková, D.; Baran, P.; Kožíšek, J.; Daïch, A.; Berkeš, D. Org. Lett. 2011, 13, 1642-1645. doi:10.1021/ol2001057

13. Ueno, M.; Kitagawa, H.; Ishitani, H.; Yasuda, S.; Hanada, K.; Kobayashi, S. Tetrahedron Lett. 2001, 42, 7863-7865. doi:10.1016/s0040-4039(01)01658-6

14. Ueno, M.; Huang, Y.-Y.; Yamano, A.; Kobayashi, S. Org. Lett. 2013, 15, 2869-2871. doi:10.1021/ol401101u

15. Saied, E. M.; Diederich, S.; Arenz, C. Chem. - Asian J. 2014, 9 , 2092-2094. doi:10.1002/asia.201402241

16. Abad, J.-L.; Armero, I.; Delgado, A. Tetrahedron Lett. 2015, 56, 1706-1708. doi:10.1016/j.tetlet.2015.02.060

17. Santos, C.; Fleury, L.; Rodriguez, F.; Markus, J.; Berkeš, D.; Daïch, A.; Ausseil, F.; Baudoin-Dehoux, C.; Ballereau, S.; Génisson, Y. Bioorg. Med. Chem. 2015, 23, 2004-2009. doi:10.1016/j.bmc.2015.03.019

18. Chacko, S.; Kalita, M.; Ramapanicker, R. Tetrahedron: Asymmetry 2015, 26, 623-631. doi:10.1016/j.tetasy.2015.04.016

19. Morita, N.; Kono, R.; Fukui, K.; Miyazawa, A.; Masu, H.; Azumaya, I.; Ban, S.; Hashimoto, Y.; Okamoto, I.; Tamura, O. J. Org. Chem. 2015 80, 4797-4802. doi:10.1021/acs.joc.5b00426

20. Lalwani, K. G.; Sudalai, A. Tetrahedron Lett. 2016, 57, 2445-2447. doi:10.1016/j.tetlet.2016.04.087

21. Snider, J. R.; Entrekin, J. T.; Snowden, T. S.; Dolliver, D. Synthesis 2013, 45, 1899-1903. doi:10.1055/s-0033-1338495

22. Xiao, Z.-F.; Yao, C.-Z.; Kang, Y.-B. Org. Lett. 2014, 16, 6512-6514. doi:10.1021/ol503261h

23. Chandrasekhar, B.; Ahn, S.; Ryu, J.-S. Synthesis 2017, 49, 1569-1574. doi:10.1055/s-0036-1588369

24. Reddy, A. A.; Prasad, K. R. J. Org. Chem. 2017, 82, 13488-13499. doi:10.1021/acs.joc.7b02611
25. Legendre, S. V. A.-M.; Jevric, M.; Klepp, J.; Sumby, C. J.; Greatrex, B. W. Tetrahedron 2018, 74, 1229-1239. doi:10.1016/j.tet.2017.11.010

26. Patro, B. S.; Maity, B.; Chattopadhyay, S. Antioxid. Redox Signaling 2010, 12, 945-960. doi:10.1089/ars.2009.2508

27. Tyagi, M.; Bhattacharyya, R.; Bauri, A. K.; Patro, B. S.; Chattopadhyay, S. Biochim. Biophys. Acta, Gen. Subj. 2014, 1840, 1014-1027. doi:10.1016/j.bbagen.2013.11.020

28. Saha, B.; Patro, B. S.; Koli, M.; Pai, G.; Ray, J.; Bandyopadhyay, S. K.; Chattopadhyay, S. Oncotarget 2017, 8, 73905-73924. doi:10.18632/oncotarget.17879

29. Bhattacharyya, R.; Gupta, P.; Bandyopadhyay, S. K.; Patro, B. S.; Chattopadhyay, S. Chem.-Biol. Interact. 2018, 285, 27-39. doi:10.1016/j.cbi.2018.02.032

30. Sheldon, R. A.; Woodley, J. M. Chem. Rev. 2018, 118, 801-838. doi:10.1021/acs.chemrev.7b00203 And the references cited therein.

31. Hughes, G.; Lewis, J. C. Chem. Rev. 2018, 118, 1-3. doi:10.1021/acs.chemrev.7b00741

32. Milnera, S. E.; Maguire, A. R. ARKIVOC 2012, No. i, 321-382. doi:10.3998/ark.5550190.0013.109

33. Carrea, G.; Riva, S., Eds. Organic Synthesis with Enzymes in Non-Aqueous Media; Wiley-VCH Verlag GmbH \& Co. KGaA: Weinheim, Germany, 2008.

34. Sharma, A.; Chattopadhyay, S. J. Org. Chem. 1998, 63, 6128-6131. doi:10.1021/jo9800513

35. Sharma, A.; Mahato, S.; Chattopadhyay, S. Tetrahedron Lett. 2009, 50, 4986-4988. doi:10.1016/j.tetlet.2009.06.069

36. Ghadigaonkar, S.; Koli, M. R.; Gamre, S. S.; Choudhary, M. K.; Chattopadhyay, S.; Sharma, A. Tetrahedron: Asymmetry 2012, 23, 1093-1099. doi:10.1016/j.tetasy.2012.06.015

37. Chatterjee, S.; Sharma, A.; Chattopadhyay, S. RSC Adv. 2014, 4, 42697-42705. doi:10.1039/c4ra05399k

38. Chatterjee, S.; Ghadigaonkar, S.; Sur, P.; Sharma, A.; Chattopadhyay, S. J. Org. Chem. 2014, 79, 8067-8076. doi:10.1021/jo5012575

39. Kanojia, S. V.; Chatterjee, S.; Gamre, S.; Chattopadhyay, S.; Sharma, A. Tetrahedron 2015, 71, 1732-1738. doi:10.1016/j.tet.2015.01.010

40. Petrier, C.; Luche, J.-L. J. Org. Chem. 1985, 50, 910-912. doi:10.1021/jo00206a047

41. Basavaiah, D.; Rao, P. D. Synth. Commun. 1990, 20, 2945-2949. doi:10.1080/00397919008051510

42. Basavaiah, D.; Rao, P. D. Synth. Commun. 1994, 24, 925-929. doi:10.1080/00397919408020766

43. Salvi, N. A.; Badheka, L. P.; Chattopadhyay, S. Biotechnol. Lett. 2003, 25, 1081-1086. doi:10.1023/a:1024136030435

44. Bracher, F.; Litz, T. Bioorg. Med. Chem. 1996, 4, 877-880. doi:10.1016/0968-0896(96)00077-6

45. Faraldos, J.; Arroyo, E.; Herradón, B. Synlett 1997, 367-370. doi:10.1055/s-1997-796

46. Mitsunobu, O. Synthesis 1981, 1-28. doi:10.1055/s-1981-29317

47. Master, H. E.; Newadkar, R. V.; Rane, R. A.; Kumar, A. Tetrahedron Lett. 1996, 37, 9253-9254. doi:10.1016/s0040-4039(96)02136-3

48. Madeira Lau, R.; Van Rantwijk, F.; Seddon, K. R.; Sheldon, R. A. Org. Lett. 2000, 2, 4189-4191. doi:10.1021/ol006732d

49. Elgharbawy, A. A.; Riyadi, F. A.; Alam, M. Z.; Moniruzzaman, M. J. Mol. Liq. 2018, 251, 150-166. doi:10.1016/j.molliq.2017.12.050 And the references cited therein. 
50. Vidya, P.; Chadha, A. J. Mol. Catal. B: Enzym. 2009, 57, 145-148. doi:10.1016/j.molcatb.2008.08.007

51. Kazlauskas, R. J.; Weissfloch, A. N. E.; Rappaport, A. T.; Cuccia, L. A J. Org. Chem. 1991, 56, 2656-2665. doi:10.1021/jo00008a016

52. Chen, C.-S.; Fujimoto, Y.; Girdaukas, G.; Sih, C. J. J. Am. Chem. Soc. 1982, 104, 7294-7299. doi:10.1021/ja00389a064

53. Theurer, M.; Fischer, P.; Baro, A.; Nguyen, G. S.; Kourist, R.; Bornscheuer, U.; Laschat, S. Tetrahedron 2010, 66, 3814-3823. doi:10.1016/j.tet.2010.03.048

54. Bachki, A.; Foubelo, F.; Yus, M. Tetrahedron: Asymmetry 1996, 7 , 2997-3008. doi:10.1016/0957-4166(96)00390-4

55. Rusina, S. V.; Litvin, E. F.; Sharf, V. Z. Russ. Chem. Bull. 1993, 42, 1200-1203. doi:10.1007/bf00702006

\section{License and Terms}

This is an Open Access article under the terms of the Creative Commons Attribution License

(http://creativecommons.org/licenses/by/4.0). Please note that the reuse, redistribution and reproduction in particular requires that the authors and source are credited.

The license is subject to the Beilstein Journal of Organic Chemistry terms and conditions:

(https://www.beilstein-journals.org/bjoc)

The definitive version of this article is the electronic one which can be found at: doi:10.3762/bjoc. 15.42 